\title{
Education, Ideology and Social Effigies: Exploring Facets from the English Course Books of the Greek State Primary Education
}

\author{
Nikos Fotopoulos ${ }^{1}$, Vicky Karra ${ }^{2}$ \& Christos Zagkos ${ }^{3, *}$ \\ ${ }^{1}$ Pedagogical Faculty, University of Western Macedonia, Florina, Greece \\ ${ }^{2}$ Department of Pre-primary Education, University of Western Macedonia, Florina, Greece \\ ${ }^{3}$ Centre of Educational Policy Development (KANEP/GSEE), Athens, Greece \\ *Correspondence: Centre of Educational Policy Development (KANEP/GSEE), $3^{\text {rd }}$ \\ Septemvriou str, 10432, Athens, Greece. E-mail: zagbal2003@yahoo.gr
}

Received: July 10, 2017 Accepted: August 2, 2017 Published: September 1, 2017

doi:10.5296/ije.v9i3.11540 URL: https://doi.org/10.5296/ije.v9i3.11540

\begin{abstract}
Textbooks are important in many ways as they influence a student or a learner inside and outside school. Since students spend quite some time on textbooks especially in the Greek society, they are regarded more important and influential than friends, teachers, school and classroom activities, games, media and society. What needs to be considered before starting the analysis is the fact that ideology plays a significant role through the process of shaping collective representations. Additionally, it is a way of referring to a world-view of a particular culture due to their drastic impact to social consciousness. It is important to mention here that the term 'culture' is used in a broad sense to denote customs, attitudes and perceptions accepted and formed by people of a society, ideas and beliefs. The present article is a critical discourse analysis of ideological contents related to culture in Greek English language books of the Greek primary state education. It critically examines the following books: English $5^{\text {th }}$ Grade and English $6^{\text {th }}$ Grade which are taught in all primary state schools in Greece. The analysis aims at finding out the cultural ideologies which are embedded in the aforementioned textbooks. Fairclough's analytical framework of Critical Discourse Analysis (henceforth CDA) will be partly implemented in order to explore cultural themes related to social events. Related often to CDA, the term ideology does not have an exact meaning or definition since it is looked at differently in several contexts, thus making its perspectives a bit elusive. However, trying to have at least a bit of understanding of it, the objectives of this discourse analysis of the Greek textbooks are: a) to see how far they pose an impact on the learners' worldviews, b) to examine the relationship between dominant ideology, national identity and textbook content, c) to interpret their role through the educational apparatuses \& d) to be aware concerning issues such as leisure time, social and cultural effigies.
\end{abstract}

Keywords: ideology, textbook, primary school, culture, consumerism, leisure time, technology 


\section{Conceptual and Theoretical Remarks}

Language ideologies are systems of socially, culturally, and historically conditioned ideas, images, and perceptions about language and communication (Blommaert, 2005). These ideologies are socially and culturally consequential because they are associated with different symbolic values (Xiong \& Yamin, 2012). Language ideologies accentuate the perceived ideas speakers have about language use, and how typically political and social characteristics are integrated into discourse (Silverstein, 1979; Irvine, 1989). The theoretical rationale of this research draws on critical educational and curriculum theories. The general position of this line of studies is that the role of education and school should be understood within the historical context of economic and sociocultural reproduction (Apple, 2004; Luke, 1989). A specific research point is exactly how the curriculum contributes to the perpetuation of existing sociocultural and economic hegemony of the dominant groups.

Keeping in mind the objectives to be mentioned it would be useful to refer to the type of schools in Greece as well as the textbooks taught in them in order to acquaint the reader to the research sites. Specifically, these schools are quite affordable to all students, especially the lower and lower-middle classes since they charge no school or book fees thus being totally dependent on the government funds in the grant of funds, building maintenance, provision of teachers and books. The students, however, have to pay for their stationery which can throughout the school year prove to be exorbitantly expensive. This means that, however the public formal education in Greece is both free of charge and affordable to all, its quintessence remains extremely unequal and problematic.

The English textbooks in public schools are free of charge and are written and published by the provincial boards under the guidelines of the Ministry of Education. Additionally contexts and curricula are under the exclusive control of the Greek State without a broader sense of pedagogical flexibility for school teachers. They are originally destined for children of the Western schools so the author/s play an important role for researching and compiling the information and prepare the manuscript according to the specifications. (Borovilos, 2007).

Living in a globalised society, we are witnessing an increasing trend of multiculturalism, fact which has a drastic impact on traditional ways of communication and interpretation of the social reality. Undoubtedly, customs, beliefs, effigies and representations of public sphere are under a continuing process of transformation through a global world which is rapidly changing. With no doubt, this new reality has provoked a lot of changes through the social institutions alternating the role and the mission of the educational system.

For instance, one of the biggest challenges for the modern state was to use educational apparatuses as a tool for understanding the 'other', having to do with diverse ethnic identities, languages and cultures. In this concept the role of education remains extremely significant for the reproduction of the dominant ideology through the fields of social relations, structures and institutions.

As a consequence, school textbooks have become one of the most powerful tools as agents of change, playing a significant role in the integration and "homogenization" of different social, 
ethnic and cultural groups. As a means of ideology by those who have the power to both develop and control them they are seen as an ideology investment functioning to impart worldview/s to their readers.

With no doubt, this strategy is based on the origin of "Modernity" and the tradition of cultural tolerance where the Era of Enlightenment has been formed since the $17^{\text {th }}$ century. Additionally, through this venture there was a common concept that the "Westernization" should play the main role of dominant powers against less developed countries ensuring that the "centre" must be the leader for the "periphery". It is very clear that, according to this concept, the educational system could play a crucial role in the reproduction and maintenance of the dominant ideology. For instance, "Galbraith states that this "social conditioning through schooling is the most important way of changing worldview whether taken by business organisation or by the state' (1984:131-4). For instance, the English textbooks taught in Greek state schools mostly represent the Western cultures as well as the American and Australian ones respectively. The contents in the former ones tend to make the students more nationalistic and patriotic. This shows that discourse can easily be manipulated to create different identities and maintain dominance something that unfortunately the educational institutions do not easily realise that discourse functions as a bearer of ideology.

Hence, those (individuals/institutions) who have this knowledge shape and subjugate those who have not (Foucault, 1975); they use 'a very powerful tool; that is language, to materialise their wishes and aspirations' (Rahimi and Sahragard, 2006). As we can see, here there is a strong correlation between the bipolar "knowledge and power" showing that everyone who has the power to shape the framework of knowledge can determine decisively the construction of collective beliefs, customs, figures and effigies.

Additionally, it has been approved via the study and dissemination of language that we can penetrate drastically opening new directions of "colonization" through the scope of culture. It is broaden accepted that the triangle: language - consciousness - way of living, constitute basic dimensions of each effort of what we call "cultural imperialism". Apart from textbooks there is also a high influence from other factors such as "culture industry", "industry of leisure time", life style industry" e.t.c.

Nowadays, there has been a great realisation of the need to fully analyse and understand the phenomenon of education from a sociological perspective and see how it is influenced and shaped by certain ideologies thus playing a vital role in the conceptualisation and execution of education.

School designs should reduce the tensions which can possibly lead to inattentiveness and bullying by conveying friendliness, cooperation, interaction and openness. The learning environment in the $21^{\text {st }}$ century should be differentiated from the traditional education model which many adults experienced when they were young by encompassing a combination of media and devices as well as varied cultures.

Ideologies in a language are important for social and linguistic analysis in the sense that they are not only about language. Irvine (1998, p. 56) defines language ideologies as "the cultural 
system of ideas about social and linguistic relationships, together with their loading of moral and political interests". Among languages, English is the most frequently taught second language throughout the world. Meanwhile, as Seargeant (2008, p. 3) argues "The subject of English in the world is one that is predominantly ideology-led".

In Greece, the teaching of the English language has been so widespread that apart from the courses taught in both private and governmental primary and secondary schools there have been established several private language institutions in which textbooks published in countries other than Greece are taught.

Textbooks taught in primary state schools are part of a system reinforcing a sense of cultural coherence providing the main source of getting information on the culture and the language for those studying it. Textbook is defined by Stray (1994) as "a book designed to provide authoritative pedagogic version of an area of knowledge" (p. 2). Researchers like Venezky (1992 cited in Lebrun et al., 2002, p. 437), views the textbook as "a cultural artefact and as a surrogate curriculum".

Concluding, the aim of this paper is:

- to emerge the role of textbooks through the construction of collective representations

- to highlight basic facets of representation of Cultures

- to interpret the hegemony of the dominant ideology through the educational apparatuses focusing on the specific role of textbooks

- to enrich the scientific debate on these matters.

\section{Data \& Methodological Remarks}

The choice of appropriate methods (data selection, collection and analysis) depends upon the object of research. The paper is based on a qualitative approach using the tool of Critical Discourse Analysis (CDA). This particular methodology entails some form of detailed textual analysis and is primarily interested and motivated by pressing social issues, which it hopes to better understand through discourse analysis (Van Dijk, 1993). CDA sees language as social practice (Fairclough \& Wodak 1997), and considers the context of language use to be crucial (Wodak 2000). It specifically includes a combination of interdiscursive analysis of texts and linguistic and other forms of semiotic analysis (Fairclough, 1993). The fundamental assumption of this methodology is a social semiotic position suggesting that text producers use various linguistic mechanisms to shape the texts intentionally and purposefully and text analysts (receivers) can recover these intentions and purposes by scrutinizing the way the grammatical mechanisms are employed (Fairclough, 1992, 1995; Martin \& Wodak, 2003).

For the purpose of our research we have chosen concrete parts from the official textbooks in order to create a hermeneutical framework concerning the function of representations through the school studying and teaching. Additionally, we have highlighted three basic categories showing how they are promoted by the textbooks producing collective effigies and images 
ones respectively. At the same time via this tool we try to analyze main figures operate through the textbooks reproducing the sovereign facets of the dominant ideology and social stratification.

Data in this research comes from the English Textbooks of $5^{\text {th }}$ and $6^{\text {th }}$ grade of Primary State Schools which are written as well as published by the Ministry of Education. The students in these classes are normally 10 to 11 years old. In the textbooks there are 10 Units containing 3 lessons. All lessons are divided in skills, language focus and cross curricular learning. All these lessons directly or indirectly relate to themes such as nationalism, society, science, traditions, environment, the arts, sports. However, the present analysis focuses solely on those lessons and contents related to us versus them, culture and the English language. Specifically we have focused on three main categories: a) Representations of culture b) the image of self between "us" and "them", c) the "consumerism" as main tendency through the advanced capitalist societies. The analysis has been carried out in the sentence level randomly selected from the textbooks trying to give a first diagnosis concerning the crucial role of textbooks through the educational process.

\section{Indicative Representations of Culture}

Language and culture are interrelated. A language is an expression of a culture and any language course which involves learning about the cultures of the people who speak the language (Starkey, 1999). At the same time via the study of language pupils are engaged energetically through the symbols, beliefs and "social standards" operated in the whole society creating common attitudes and concepts of themselves. Language as communicative tool plays a significant role transmitting values, customs and cultural facts from one generation to another. In other words remains the main mechanism for the construction of social and cultural consciousness of a modern nation - state. Expanding this perception this theme deals with the representation of Western culture in both textbooks with a clear reflection of the Western society including various national and cultural events to inculcate the readers with nationalistic and cultural fervour.

This indicates that students not only learn about the indigenous cultures but about other Western and world cultures as well. From a representational point of view, we are going to focus on the western world (specifically the ideal type of advanced capitalist societies) represented in form of practices, values and conceptions of life in the English $5^{\text {th }}$ Grade textbook to illustrate the social messages these instances impart on the young learners.

- Pedro loves riding his bike and drawing. He is also fond of surfing the Net and chatting to children from all over Europe.(English $5^{\text {th }}$ Grade textbook, p.23)

The lines are a reflection of the Western culture where children of a young age are allowed to fully explore the world without any serious restrictions thus making them take responsibility for their decisions and actions. They seem carefree as their leaving home to ride their bikes seems a completely normal and regular social practice as this gives them a further chance to discover the world. Also, the fact that they can get in touch with unknown people from a 
distance using the new technologies adds to the fact that they are offered an adventurous world in contrast to other cultures for example in Pakistan where this freedom does not seem to be the case.

Along with the instances of the adventurous life, the textbooks also replete with the instances of Christianity. It is about Easter day and deals with it in a very liberal way as follows:

- On Easter Day, all people of this Greek village attended the mass and then walked to the countryside. The Eastern tables were set and the men were roasting the Easter lamb. They sat down at the tables, offering Papa-Kyriakos, the priest, a special seat. And then the feast began. They were eating happily, enjoying their Easter meal after a 40-day fast. Grown-ups were drinking local wine and joking while children were playing and singing, wishing everybody 'Happy Easter'. (English $5^{\text {th }}$ Grade Textbooks, p. 106)

This scene indicates the way Easter is celebrated all over Greece. It indicates that the Greeks indicate religious events as sacred thus celebrating them in full zeal. The religious fervour presents them as enthusiasts, people who do nothing to suppress their emotions and feelings on such occasions. They rather express them through illuminations of traditional food, and having a good time with each other.

The presence of 'the mass and the priest' in the sample text can be taken as metaphors for world and religion respectively as they can be seen as going side by side in their lives. Or there is a dialectical relationship between them - religion teaches them how to live a life and living a life accordingly is likely to result in a success in this life and the life hereafter. Looking at it from another angle, people think of religion as a source of peace, tranquillity, and satisfaction in life; hence, being away from religion signifies being distanced from a peaceful life.

\subsection{Us and Them}

The presence of particular identities in the textbooks function not only to distinguish but also to gap the distance of one from the other either on social or cultural basis, hence under analysis the textbooks do not emphasise a lot on differences lying among European, neighbouring or other English speaking countries but try to create only one identity.

Looking at the following text taken from the English $5^{\text {th }}$ Grade book

- I have many friends around Europe and in other parts of Ireland. We use the Internet to find information, to talk or play computer games, especially at the weekends Do you do the same in Greece? (page 15)

we can undoubtedly realise the attempt of uniting all European countries as far as a particular free time activity is concerned; that of online chatting. By encouraging Greek students to think and give an answer at the question 'Do you do the same in Greece?' they do not feel excluded from the European norm as it is a frequent pastime activity to chat online with friends or even use online information for school projects. 
However, the textbooks include negative out-group representations through the us-and-them representation. They do not of course represent the others as enemies but rather as inferior through a negative description of themes related to status and position in a society as it is represented in the $1^{\text {st }}$ Unit of the $6^{\text {th }}$ Grade textbook

- Albania, the ancient Illyria, is where I come from. My hometown is Tirana, the capital of Albania. Albania shares boarders with Serbia, Montenegro and Greece. ....................... country is not very rich and our parents sometimes go to other countries such as Italy, France or Greece, and work there. However, we miss our homeland. (p.2)

and in the same Unit of the same textbook again we see the same inferior picture through the lines

- That is where I come from, Georgia! Many people work in copper and coal mines, or in oil wells. Others sometimes leave their hometown to find work. (p.2)

The job status represented in these lines, roughly position these cultures among the developed ones as it is associated with job insecurity and lack of career paths. There exists the tendency of moving to another town or country in order for job security to be achieved; job security sought after in inferior jobs such as workers in copper and coal mines. This could be a result of economic, intellectual, social and political death. Inferior jobs, inferior housing, inferior education which all in turn again lead to inferior jobs.

Again, in line 10 in the $6^{\text {th }}$ Grade textbook we find another connotation of inferiority, this time of Europe's migration crisis.

- The people of Britain are multicultural, coming from different countries and races, so here you can meet British people from Asia, Africa or the Caribbean. They speak English and the language of their fathers as well. I think it's exciting to live in Great Britain because it opens its doors to everyone!

The citizens of the aforementioned countries almost always have the legal right to refuge in Europe. Many claim that Britain is a coveted destination for migrants because of its generous benefits system. Aside from the reality that most migrants have little prior knowledge of the exact nature of each European country's asylum system, it is not true that the UK is particularly beneficent.(Note 1)

Superiority of English is another most frequent ideology. It can be manifested through the superiority not only of the English language but also of the English culture and superiority of English-speaking countries. For example, in the English $6^{\text {th }}$ Grade Textbook there is a Geography project in page 10 and even if the unit is entitled Our multicultural class, the model text to work with has to do with a pupil presenting his own country which is no other than Great Britain.

- My name is Gwen and I am ten years old. It is a Welsh name, because my father comes from Wales but now I live in Oxford, England. The official name of my country is The United Kingdom of Great Britain and Northern Ireland and it includes Great 
Britain (England, Wales and Scotland) and Northern Ireland.

Also, in Unit 4 of the English $5^{\text {th }}$ Grade textbook, where there is an exposition of Christmas everywhere meaning that we expect to learn about other countries as well and how they celebrate Christmas, the predominant country presented is the USA as Lesson 2 (pages 54-55) is entitled Kostas is in New York for Christmas. Through his holidays there, we are shown how to make pancakes which is one of the most traditional American desserts during Christmas day.

As Kubota (1998) notes one of the ideological aspect of teaching and learning English is the construction of cultural stereotypes and trivialization of content. The negative side of American society including poverty, crime, illiteracy, racism, and so forth is rarely touched upon. Lummis (1976, cited in Kubota, 1998) pointed out that the images of the United States presented in English classes are what native teachers wish.

\subsection{Consumerism}

Consumerism is a promoted ideology in the English primary state school textbooks presented through shopping and technology. For instance, in the English $6^{\text {th }}$ Grade textbook (page 14) there is an advertisement of a luring supermarket selling all the necessary products for any possible occasion.

- At FFM's (Fresh Food Market) you can find a great selection of delicious and tempting cakes and desserts. Choose from fresh cream cakes and fruit flans to tasty pastries and delicious muffins-many prepared in-store. The boxes of doughnuts include a range of tempting flavours. For any special occasion there's a great range of celebration cakes too!

A picture of displayed products is displayed to persuade the reader.

Also, in the same textbook in page 21 there is a role-play being promoted between two pupils to make a conversation between a salesperson and a customer and it can be observed how the salesperson is going to try his best in order to persuade the buyer to buy products.

- Pupil A

You are the customer and you are trying to buy the things you want. Ask questions like:

How much is it/are they?

What is it made of? Etc

\section{Pupil B}

You are trying to sell your things to the customer. Answer the customer's questions.

Also, following the trend of the use of modern technologies, there is a promotion of the ideology of consumerism through e-shopping. In page 22 of the English $6^{\text {th }}$ Grade textbook, pupils get triggered by the notion of comfort buying through the Internet without having to move from their home thus wasting precious time. Several pictures of products found online 
along with numerous information related to them are all in front of their eyes to choose from, compare and finally get persuaded to buy.

- John and Mary are looking for some toys on the Internet. Here is a site where they can look at, order and buy toys on-line. If you click on the picture you can find more information on the toy you are interested in.

\section{Conclusion}

This article has aimed at presenting some of the ideologies embedded in the English textbooks of primary state schools in Greece. As Oakes (2001) states, a language is more than just a means of communication, is its symbolic value that language is often perceived as an institution, an entity in its own right. Simultaneously, language constitute one of the greatest channels of dominant ideology through the educational apparatuses, playing a significant role for the maintenance and reproduction of the sovereign status quo. It is worth mentioning that the findings of this paper should not be generalized after they can be used as initial facts for a basis of critical approach and rethinking through the scope of our analysis. With no doubts, this qualitative approach can be seen as a first outline of what could be the role of textbooks for the construction of the collective representations through the primary public education in Greece.

The term 'ideologies' is used as textbooks are the carriers of different ideologies related to "religion", "us and them", "consumerism" and "technology" in the present study offering valuable insights to textbook writers and curriculum designers in designing English teaching courses, writing textbooks, and developing language curricula. At the same time through the function of ideology we observe to be generated many kinds of social representations that affect the way of living of social subjects. Stereotypes, social and cultural attitudes, beliefs and customs constitute the core of the social consciousness, shaping the mainstream of thinking, living and perceiving the external objectivity. Undoubtedly, ideology affects all means of social action through the whole society, drastically.

Defining the term language ideology is not entirely unproblematic, seeing as there has been ambiguity concerning the definition of ideology itself (Hawkins, 2001). Overall, it seems that language ideology is an undeniable fixture in society. One can assume that it explicitly or implicitly permeates such large social institutions as schools, and consequently the teaching materials schools use.

Through textbooks teachers become more and more aware of the cultural values and how to convey them without causing any shock to the learners. It is by drawing attention to the factors that lead to cultural conflict and culture shock that intercultural understanding can be promoted (Bambgose, 1994). Further, awareness of the influence of the culture of a dominant language is necessary because the long-term influence may lead to a loss of confidence in the values of the less dominant language and culture.

As early as 1931, Brother Marie Victorin wrote, "Without denying the usefulness of textbooks, 
I wonder if we haven't exaggerated their importance. We must realize that if we're not careful, books, and textbooks in particular, soon cease to be a mirror and instead become a screen which, instead of broadening thought, can easily repress it, restrain it, and lock it up in the terrible prison-house of words" (Aubin, 1997, p. 12).

\section{References}

Apple, M, W. (2004). Ideology and curriculum. New York and London: Routledge Falmer.

Aubin, P. (1997). Le manuel scolaire dans l'historiographie québécoise. Sherbrooke: University of Sherbrooke, Groupe de recherche sur l'édition littéraire au Québec.

Blommaert, J. (2005). Discourse: A critical introduction. Cambridge: Cambridge University Press

Borovilos, A. (2007). Publishing with the school division. Retrieved on May 28, 2008 from http://www.oupcanada.com/school/publishing_school.html

Fairclough, N., \& Wodak, R. (1997). Critical Discourse Analysis’ In: van Dijk, T.A. (ed.), Introduction to Discourse Analysis. London, 258-284.

Fairclough, N. (1992). Discourse and social change. Cambridge: Polity Press.

Fairclough, N. (1993). Critical discourse analysis and the commodification of public discourse, Discourse and Society, 4(2), 133-68.

Fairclough, N. (1995). Critical discourse analysis. London: Longman.

Foucault, M. (1975). Discipline and Punish: The Birth of the prison, Random House: New York.

Galbraith, J. (1984) The Voice of the Poor: Essays in Economic and Political Persuasion. Harvard University Press.

Hawkins, B. (2001). Incorporating tensions: On the treatment of ideology in cognitive linguistics. In R. Dirven, B. Hawkins \& E. Sandikcioglu (Eds.), Language and ideology. Volume I: Theoretical cognitive approaches (pp. 1-22). Amsterdam: John Benjamins Publishing Company

Irvine, J. T. (1989). When talk isn't cheap: Language and political economy. American Ethnologist, 16(2), 248-267. https://doi.org/10.1525/ae.1989.16.2.02a00040

Irvine, J. T. (1998). Ideologies of Honorific language. In B. B. Schieflin, A. K Woolard, \& P. V. Kroskrity (Ed.), Language ideologies (pp. 51-67). Oxford: Oxford University Press.

Kubota, R. (1998). Ideologies of English in Japan. World Englishes, 17(3), 295-306.

Lebrun, J, et.al. (2002). Past and current trends in the analysis of textbooks in a Quebec context. Curriculum Inquiry, 32(1), 51-83. https://doi.org/10.1111/1467-873X.00215 
Luke, A. (1989). Open and closed texts: The ideological/semantic analysis of textbook $\begin{array}{lllll}\text { narratives. } \quad \text { Journal } & \text { of }\end{array}$ https://doi.org/10.1016/0378-2166(89)90109-4

Martin, J.R., \& Wodak, R. (Eds.). (2003). Re/reading the past: Critical and functional perspectives on time and value. Amsterdam: John Benjamins.

Oakes, L. (2001). Language and national identity: Comparing France and Sweden. Amsterdam: John Benjamins Publishing Company

Rahimi \& Sahragard. (2006, January). A CDA of euphemization and derogation in e-mails on the late Pope. The Linguistics Journal, 2. https://doi.org/10.7575/ijalel.v.1n.5p.1

Seargeant, P. (2008). Language, ideology, and 'English within a globalized context'. World Englishes, 27(2), 217-232. https://doi.org/10.1017/S0261444800008879

Silverstein, M. (1979). Language structure and linguistic ideology. In P. R. Clyne, W. F. Hanks \& C. L. Hofbauer (Eds.), The elements: A parasession on linguistic units and levels (pp. 193- 247). Chicago, IL: Chicago Linguistic Society.

Singh, I. (1999). Language, thought and representation. In Ishtla Singh and Jean Stilwell Peccei. (Ed.), Language, society and power (pp. 17-34). London: Routledge.

Starkey, H. (1999). Foreign language teaching to adults: Implicit and explicit political education. Oxford Review of Education, 25(1), 155-169. https://doi.org/10.1080/030549899104189

Stray, C. (1994). Paradigms regained: Towards a historical sociology of the textbook. Journal of Curriculum Studies, 26(1), 1-29.

Van Dijk, T.A. (1993) Discourse, Power and Access. In C.R. Caldas (ed.), Studies in Critical Discourse Analysis. London: Routledge

Wodak, R. (2000). Recontextualisation and the transformation of meaning: a critical discourse analysis of decision making in EU-meetings about employment policies. In: Sarangi, S./ Coulthard, M. (eds.), Discourse and Social Life. Harlow: Pearson Education, 185-206.

Xiong, T., \& Yamin Q. (2012): Ideologies of English in a Chinese high school EFL textbook: a critical discourse analysis, Asia Pacific Journal of Education, 32(1), 75-92. https://doi.org/10.1080/02188791.2012.655239

Note

Note 1. See

http://www.theguardian.com/uk-news/2015/aug/10/10-truths-about-europes-refugee-crisis 


\section{Copyright Disclaimer}

Copyright for this article is retained by the author(s), with first publication rights granted to the journal.

This is an open-access article distributed under the terms and conditions of the Creative Commons Attribution license (http://creativecommons.org/licenses/by/3.0/). 